Article

\title{
Probabilistic Analysis of Major Construction Materials in the Life Cycle Embodied Environmental Cost of Korean Apartment Buildings
}

\author{
Seungjun Roh ${ }^{1} \mathbb{D}$, Sungho Tae ${ }^{1,2, *}$, Rakhyun Kim $^{1}$ and Suroh Park ${ }^{1}$ \\ 1 Sustainable Building Research Center, Hanyang University, Ansan 15588, Korea; sjroh@hanyang.ac.kr (S.R.); \\ redwow6@hanyang.ac.kr (R.K.); elijahsu@hanyang.ac.kr (S.P.) \\ 2 Department of Architecture \& Architectural Engineering, Hanyang University, Ansan 15588, Korea \\ * Correspondence: jnb55@hanyang.ac.kr; Tel.: +82-31-400-5187
}

Received: 14 November 2018; Accepted: 29 January 2019; Published: 6 February 2019

check for updates

\begin{abstract}
This study employs probabilistic analysis to evaluate the life cycle embodied environmental cost of Korean apartment buildings, with a focus on six major construction materials. To this end, the bill of materials was analyzed for 443 Korean apartment buildings according to the type and plan form, and probability density functions (PDFs) were established for the input quantities of the six materials under consideration. Life cycle scenarios were then examined for each material, and their respective life cycle embodied environmental cost factors were established, using a monetary valuation-based damage cost life cycle analysis model. The estimated environmental costs were evaluated by apartment structural type and plan form, based on probability distributions using the Monte Carlo simulation (MCS). Building life cycle embodied environmental cost was estimated between $16.87 \mathrm{USD} / \mathrm{m}^{2}$ and $23.03 \mathrm{USD} / \mathrm{m}^{2}$ (90\% confidence interval). Among the structure types analyzed, the highest costs were associated with the wall structure, followed by rigid frame and flat plate structures; at the plan form level, costs followed the sequence plate-type $>$ mixed-type $>$ tower type for a given type of structure.
\end{abstract}

Keywords: life cycle embodied environmental cost; apartment building; major construction material; probabilistic analysis

\section{Introduction}

In recent years, sustainable development has been recognized as an international agenda that addresses global environmental problems while contributing to the balanced development of human society [1].

The construction sector is working towards encouraging the introduction of quantitative evaluation models for sustainable buildings, to reduce the potential environmental impacts of buildings and enhance the quality of life for residents, in line with the principles of sustainable development [2-6]. For example, Robichaud et al. [7] suggested four elements for a quantitative evaluation of buildings' sustainability which are the minimization of environmental impact, the enhancement of residents' health, the return of investments, and the introduction of the life cycle in the design phase. Zuo and Zhao [8] presented three elements, the reduction of environmental impacts, the creation of economic profits, and the enhancement of comfort and health, which can be achieved through the reduction of construction materials, operating energy consumption and waste products. Kang [9] also suggested sustainability evaluation factors that consisted of the reduction of environmental impact focusing on global warming, the saving of life cycle costs and indirect costs, and the enhancement of residents' health and comfort, and developed a conceptual evaluation model based on these items. 
Environmental impact can be defined as possible adverse environmental effects caused or induced by human activities and technologies. There are various categories of environmental impact, designated as quantifiable concepts, such as global warming potential (GWP), acidification potential (AP), eutrophication potential (EP), ozone layer depletion potential (ODP), photochemical oxidation potential (POCP), and abiotic depletion potential (ADP) [10-12]. A building's potential environmental impact throughout its life cycle consists of embodied impacts and operational impact [10,13,14]. Embodied environmental impact equals the sum of all environmental impacts associated with construction materials, i.e., the environmental impacts caused by all construction material-related processes, such as their production and transportation; the materials used for construction; repair materials used for building management; and demolition waste. Operational environmental impacts encompass the environmental impact associated with a building's operational energy consumption throughout its service life.

The construction sector has put much work into reducing the environmental impacts of buildings during their life cycle. Such efforts have focused on the operational environmental impact due to its higher magnitude, which results from the extremely long service life and huge energy demand of buildings compared with general consumer products [15-18]. In recent years, however, there is an increasing demand for research to intensively evaluate and reduce not only the operational environmental impact but also a building's embodied environmental impact caused by construction materials [19-24]. To meet this demand, developed countries such as the US, UK, Germany, and South Korea are evaluating the life cycle embodied environmental impacts associated with construction materials, according to the criteria stipulated in their respective building codes and green building certification systems [8,25-30]. Alongside this, some researchers have presented new approaches for effectively evaluating a building's life cycle embodied environmental impacts, and have conducted various case studies in an attempt to reduce these [31-39]. For example, Huang et al. [31] explored building material consumption and the embodied greenhouses gases emission from buildings constructed in Shanghai through life cycle assessment (LCA). Basbagill et al. [32] presented a method to reduce embodied environmental impacts, in which LCA is applied in the early planning stage of a construction project. Azari and Abbasabadi [33] provided an overview of the literature on embodied energy use in buildings in several aspects. Meneghelli [34] conducted a sensitivity analysis to identify the effects of construction materials on a building's life cycle environmental impact. Malmqvist et al. [35] collected a comprehensive overview of quantitative reduction potentials of the embodied greenhouses gases reduction strategies, which should be considered by the stakeholders engaged in, and with the capacity to influence the outcome of, individual building projects. Chastas et al. [36] normalized the embodied $\mathrm{CO}_{2}$ emissions of residential buildings in their review of prior case studies on embodied environmental impact. Li et al. [37] presented and analyzed a system for evaluating the embodied $\mathrm{CO}_{2}$ emissions of residential buildings in China. The results of these studies are used as basic data for quantitative analysis of a building's life cycle environmental impacts, and for research and policy geared towards reducing them efficiently. However, most previous studies evaluated only one or two buildings. To improve the applicability of study results as basic data for planning and implementing reductions in buildings' life cycle environmental impacts, there is a need for research with the following foci:

- Evaluation of embodied environmental impacts of buildings, comprehensively considering various environmental impact categories associated with buildings, as recent studies on buildings or construction materials are showing [26,40].

- Presentation of the research findings on embodied environmental impacts in an easily understandable manner, given that comparison and interpretation of evaluation results concern different environmental impact categories and their respective standard materials. To address this problem, a new, integrated approach known as environmental cost has recently been introduced, in which end-point environmental problems attributable to various environmental impacts are presented as monetary values [41,42]. 
- Evaluation of the embodied environmental impacts of all existing buildings, by employing a sufficient number of samples considering different buildings in terms of structure type and plan form, and estimating their characteristics; because an analysis of embodied environmental impacts based on only a small number of buildings cannot be considered representative of all existing buildings [41].

Against this background, the present study employs probabilistic analysis to evaluate the life cycle embodied environmental costs of apartment buildings in South Korea, focusing on six major construction materials, i.e., ready-mixed concrete (RMC), rebar, concrete brick, glass, insulation (expanded polystyrene and expanded polypropylene), and gypsum board which account for more than $95 \%$ of environmental impacts within the six impact categories (GWP, AP, EP, ODP, POCP, and ADP) [43].

\section{Materials and Methods}

This section describes the process of evaluating the life cycle embodied environmental costs of apartment buildings in South Korea according to structure type and plan form, based on probabilistic analysis. The probabilistic analysis method defines an uncertain variable expected to occur in real life as a numerical probability density function (PDF), and calculates the expected results and probabilities by means of probability distributions [44]. This method has various advantages. Firstly, it extracts not only specific values (mean values, in general) using a deterministic analysis method, but also the statistical properties of the results, such as mode; minimum, maximum, and expected values and probability distributions. The method also has the advantage that it can be combined with simulation methods such as the Monte Carlo simulation (MCS) for sample-based population estimation and that it can analyze the evaluation results separately according to range and segment, based on probability distributions $[45,46]$. Therefore, probabilistic analysis was selected as a descriptive approach for estimating the embodied environmental costs of the target sample (i.e., all apartment buildings constructed in South Korea) on the basis of evaluating a sufficient number of samples and for establishing a mathematical model for evaluating a building's embodied environmental cost (Equation (1)), drawing on the LCA conceptual equation [47] for quantifying the environmental impact of a product or service (Equation (2)). We then analyzed the input quantities of the six major construction materials of 443 apartment buildings constructed in South Korea, and established PDFs of the input quantities of these construction materials according to the structural types and plan forms of the apartment buildings. Additionally, we examined life cycle scenarios for each of the six construction materials, and computed the life cycle embodied environmental cost factor using the Life Cycle Inventory (LCI) database and KOLID methodology (Korean Life cycle Impact assessment method based on damage-oriented modeling), which is a monetary valuation-based model used in South Korea for analyzing the costs of damage at the life cycle scale [42]. The obtained PDFs of the input quantities and the life cycle embodied environmental cost factors of the major construction materials were then subjected to 10,000 MCS iterations, and the life cycle embodied impacts, according to structure type and plan form, were presented as probability distributions. The workflow of investigation is presented in Figure 1.

$$
\begin{aligned}
P\left(E C_{A}\right) & =\sum_{\mathrm{i}=1}^{\mathrm{n}}\left(A_{P(i)} \times C C_{i}\right) \\
E I_{A} & =\sum_{\mathrm{i}=1}^{\mathrm{n}}\left(A_{i} \times I F_{i}\right)
\end{aligned}
$$

In Equation (1), $P\left(E C_{A}\right)$ is the probabilistic life cycle embodied environmental cost of building $A, A_{P(i)}$ is the PDF of the input quantity of construction material (i) utilized in building $A$, and $C C_{i}$ is the life cycle embodied environmental cost factor of construction material (i). In Equation (2), $E I_{A}$ is the environmental impact of product or service $A, A_{i}$ is the input quantity of material or energy (i) for product or service $A$, and $I F_{i}$ is the environmental impact factor of material or energy $(i)$. 


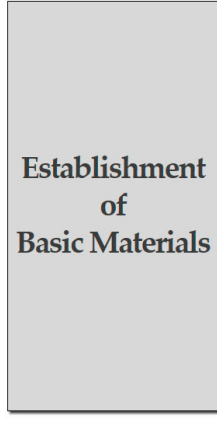

Probabilistic Analysis Model

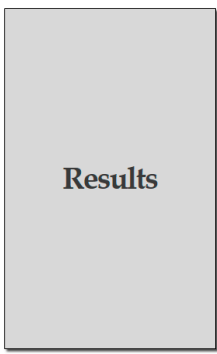

Probability Density Function of

Major Construction Materials

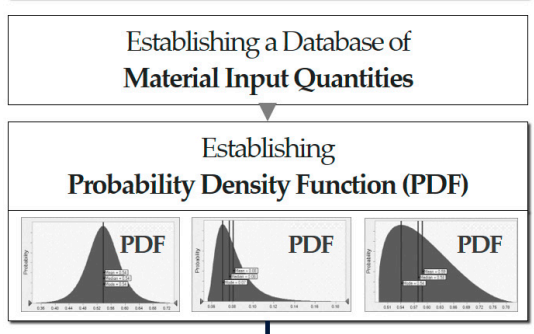

Environmental Cost Factor of

Major Construction Materials

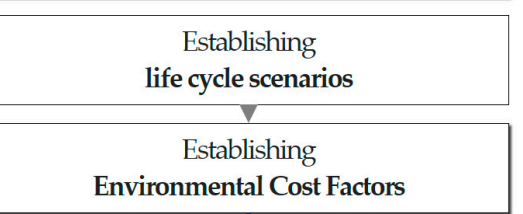

\section{INPUT}

Application of Monte Carlo Simulation (MCS)

[Equation 2] Model Equation of Probabilistic Life Cycle Embodied Environmental Cost

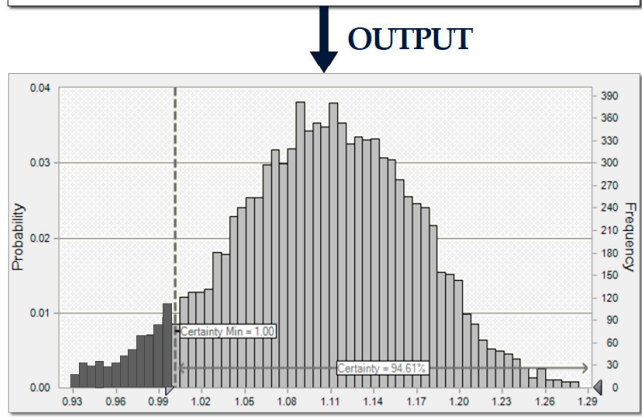

Figure 1. Workflow of investigation.

\subsection{Establishing Probability Density Functions of Major Construction Materials}

\subsubsection{Establishing a Database of Material Input Quantities}

Table 1 presents the number of buildings of each structure type and plan form $(n=443)$, to enable extrapolation to all apartment buildings constructed in South Korea. For each building, we established the input quantities of the six major construction materials, resulting in a database of input quantities per unit area [41]. The major construction materials selected in this study are RMC, rebar, concrete brick, glass, insulation, and gypsum board. Among all construction materials used in an apartment building, these six collectively account for more than $95 \%$ of environmental impacts within the six impact categories (GWP, AP, EP, ODP, POCP, and ADP) [43,48-50]. This input quantity database considers the six major construction materials used for the above-ground floors, on the assumption that the total quantities of all materials are used for construction, as specified in the original bill of materials. This is because the input quantity of construction materials could be varied during the actual construction process, and in particular, the input quantity of construction materials used for underground floors could vary significantly depending on the basement and ground structure. Table 2 shows examples of major construction material inputs for 9 different types of apartment building.

Table 1. Number of samples.

\begin{tabular}{ccccccccc}
\hline & Wall Structure & \multicolumn{2}{c}{ Rigid Frame Structure } & \multicolumn{3}{c}{ Flat Plate Structure } \\
\hline Plate-type & Tower-type & Mixed-type & Plate-type & Tower-type & Mixed-type & Plate-type & Tower-type & Mixed-type \\
\hline 118 & 101 & 60 & 22 & 40 & 64 & 6 & 22 & 10 \\
\hline
\end{tabular}


Table 2. Examples of quantity DB of major construction materials.

\begin{tabular}{|c|c|c|c|c|c|c|c|c|c|c|c|}
\hline \multirow[b]{2}{*}{ No. } & \multirow[b]{2}{*}{$\begin{array}{c}\text { Structure } \\
\text { Type }\end{array}$} & \multirow[b]{2}{*}{ Plane Form } & \multirow[b]{2}{*}{$\begin{array}{l}\text { No. of } \\
\text { Stories }\end{array}$} & \multirow[b]{2}{*}{$\begin{array}{l}\text { Building } \\
\text { Area }\left(\mathrm{m}^{2}\right)\end{array}$} & \multirow{2}{*}{$\begin{array}{c}\text { Exclusive } \\
\text { Use Area } \\
\left(\mathrm{m}^{2}\right)\end{array}$} & \multicolumn{6}{|c|}{ Quantity of Major Construction Materials per Exclusive Use Area } \\
\hline & & & & & & $\underset{\left(\mathrm{m}^{3} / \mathrm{m}^{2}\right)}{\mathrm{RMC}}$ & $\begin{array}{c}\text { Rebar } \\
\left(\mathrm{kg} / \mathrm{m}^{2}\right)\end{array}$ & $\begin{array}{c}\text { Concrete } \\
\text { Brick } \\
\left(\mathrm{kg} / \mathrm{m}^{2}\right)\end{array}$ & $\begin{array}{c}\text { Glass } \\
\left(\mathrm{m}^{2} / \mathrm{m}^{2}\right)\end{array}$ & $\begin{array}{c}\text { Insulation } \\
\left(\mathrm{kg} / \mathrm{m}^{2}\right)\end{array}$ & $\begin{array}{c}\text { Gypsum } \\
\text { Board } \\
\left(\mathrm{kg} / \mathrm{m}^{2}\right)\end{array}$ \\
\hline 1 & \multirow{3}{*}{$\begin{array}{c}\text { Wall } \\
\text { Structure }\end{array}$} & Plate-type & 22 & 6709.15 & 5071.50 & 0.78 & 105.37 & 92.36 & 0.52 & 1.62 & 2.74 \\
\hline 2 & & Tower-type & 27 & 8536.10 & 6712.63 & 0.73 & 101.34 & 88.54 & 0.46 & 1.58 & 2.66 \\
\hline 3 & & Mixed-type & 27 & $17,047.41$ & $13,451.39$ & 0.75 & 99.86 & 90.35 & 0.45 & 1.61 & 2.67 \\
\hline 4 & \multirow{3}{*}{$\begin{array}{c}\text { Rigid } \\
\text { Frame } \\
\text { Structure }\end{array}$} & Plate-type & 20 & 8449.98 & 6023.50 & 0.80 & 128.21 & 91.24 & 0.45 & 1.64 & 2.70 \\
\hline 5 & & Tower-type & 15 & 4711.15 & 3290.47 & 0.60 & 145.26 & 90.14 & 0.44 & 1.59 & 2.71 \\
\hline 6 & & Mixed-type & 24 & $11,416.77$ & 8043.78 & 0.78 & 138.54 & 88.85 & 0.33 & 1.62 & 2.68 \\
\hline 7 & \multirow{3}{*}{$\begin{array}{l}\text { Flat Plate } \\
\text { Structure }\end{array}$} & Plate-type & 13 & 1881.64 & 1439.76 & 0.65 & 120.07 & 90.67 & 0.52 & 1.56 & 2.62 \\
\hline 8 & & Tower-type & 21 & 9135.18 & 6880.07 & 0.52 & 149.02 & 88.37 & 0.49 & 1.49 & 2.68 \\
\hline 9 & & Mixed-type & 15 & 5973.46 & 4679.22 & 0.76 & 137.46 & 87.80 & 0.54 & 1.53 & 2.65 \\
\hline
\end{tabular}

\subsubsection{Establishing Probability Density Function}

The PDF matrix was constructed based on the input quantities of major construction materials by structure type and plane form, as presented in Table 3. The flat plate structure sub-group contained fewer examples than the other structure types, and so was not subdivided into different plan forms when establishing the probability distributions. All PDF variables were based on exclusive use area. PDF fitting was performed using Crystal Ball commercial software for MCS, and the PDFs of major construction materials were checked against the statistics of the Anderson-Darling (A-D) test. Additionally, the input quantities of the major construction materials were assumed to be independent of each other. This is because the relationship between input quantities of construction materials is very complex and additional research is needed to understand this. Table 4 illustrates some of the PDFs for the major construction materials analyzed in this study.

Table 3. Probability density function (PDF) matrix.

\begin{tabular}{clllllll}
\hline $\begin{array}{c}\text { Structure } \\
\text { Type }\end{array}$ & $\begin{array}{c}\text { Plane } \\
\text { Form }\end{array}$ & RMC & Rebar & $\begin{array}{c}\text { Concrete } \\
\text { Brick }\end{array}$ & $\begin{array}{c}\text { Gypsum } \\
\text { Board }\end{array}$ & Glass & Insulation \\
\hline \multirow{2}{*}{ Wall } & Plate-type & PDF-01 & PDF-02 & PDF-03 & PDF-04 & PDF-05 & PDF-06 \\
Structure & Tower-type & PDF-07 & PDF-08 & PDF-09 & PDF-10 & PDF-11 & PDF-12 \\
& Mixed-type & PDF-13 & PDF-14 & PDF-15 & PDF-16 & PDF-17 & PDF-18 \\
\hline Rigid & Plate-type & PDF-19 & PDF-20 & PDF-21 & PDF-22 & PDF-23 & PDF-24 \\
Frame & Tower-type & PDF-25 & PDF-26 & PDF-27 & PDF-28 & PDF-29 & PDF-30 \\
Structure & Mixed-type & PDF-31 & PDF-32 & PDF-33 & PDF-34 & PDF-35 & PDF-36 \\
\hline \multicolumn{2}{c}{ Flat Plate Structure } & PDF-37 & PDF-38 & PDF-39 & PDF-40 & PDF-41 & PDF-42 \\
\hline
\end{tabular}

Table 4. Probability distribution of major construction materials.

\begin{tabular}{ccccc}
\hline Classification & PDF-01 & PDF-02 & PDF-04 & PDF-06 \\
\hline $\begin{array}{c}\text { Materials } \\
\text { Structure } \\
\text { Plan type }\end{array}$ & $\begin{array}{c}\text { RMC } \\
\text { Wall Structure } \\
\text { Plate-type }\end{array}$ & $\begin{array}{c}\text { Rebar } \\
\text { Wall Structure } \\
\text { Plate-type }\end{array}$ & $\begin{array}{c}\text { Gypsum Board } \\
\text { Wall Structure } \\
\text { Plate-type }\end{array}$ & $\begin{array}{c}\text { Insulation } \\
\text { Wall Structure } \\
\text { Plate-type }\end{array}$ \\
Probability & & & & \\
Distribution & & & & \\
& & & & \\
No. of Samples & Lognormal Distribution & Logistic distribution & Logistic distribution & Beta distribution \\
Variable & Exclusive Use Area & Exclusive Use Area & Exclusive Use Area & Exclusive Use Area \\
Mean & $0.77 \mathrm{~m}^{3} / \mathrm{m}^{2}$ & $98.13 \mathrm{~kg} / \mathrm{m}^{2}$ & $2.61 \mathrm{~kg} / \mathrm{m}^{2}$ & $1.39 \mathrm{~kg} / \mathrm{m}^{2}$ \\
Median & $0.76 \mathrm{~m}^{3} / \mathrm{m}^{2}$ & $98.13 \mathrm{~kg} / \mathrm{m}^{2}$ & $2.61 \mathrm{~kg} / \mathrm{m}^{2}$ & $1.38 \mathrm{~kg} / \mathrm{m}^{2}$ \\
Mode & $0.74 \mathrm{~m}^{3} / \mathrm{m}^{2}$ & $98.13 \mathrm{~kg} / \mathrm{m}^{2}$ & $2.61 \mathrm{~kg} / \mathrm{m}^{2}$ & $1.35 \mathrm{~kg} / \mathrm{m}^{2}$ \\
\hline
\end{tabular}




\subsection{Establishing Environmental Cost Factors of Major Construction Materials}

\subsubsection{Establishing Life Cycle Scenarios}

The building LCA highlights the need for a life cycle scenario for each construction material, with systemized information throughout its life cycle, namely production (A1-A3) and transportation (A4), construction (A5), replacement (B4), deconstruction of construction materials (C1), transportation of waste construction materials (C2), and disposal (incineration and landfill) (C4), in order to determine its life cycle embodied environmental cost factor.

Figure 2 illustrates the overall life cycle scenario based on the system boundary for building LCA as specified in EN 15804 [51], broken down into the individual scenarios for the six materials.

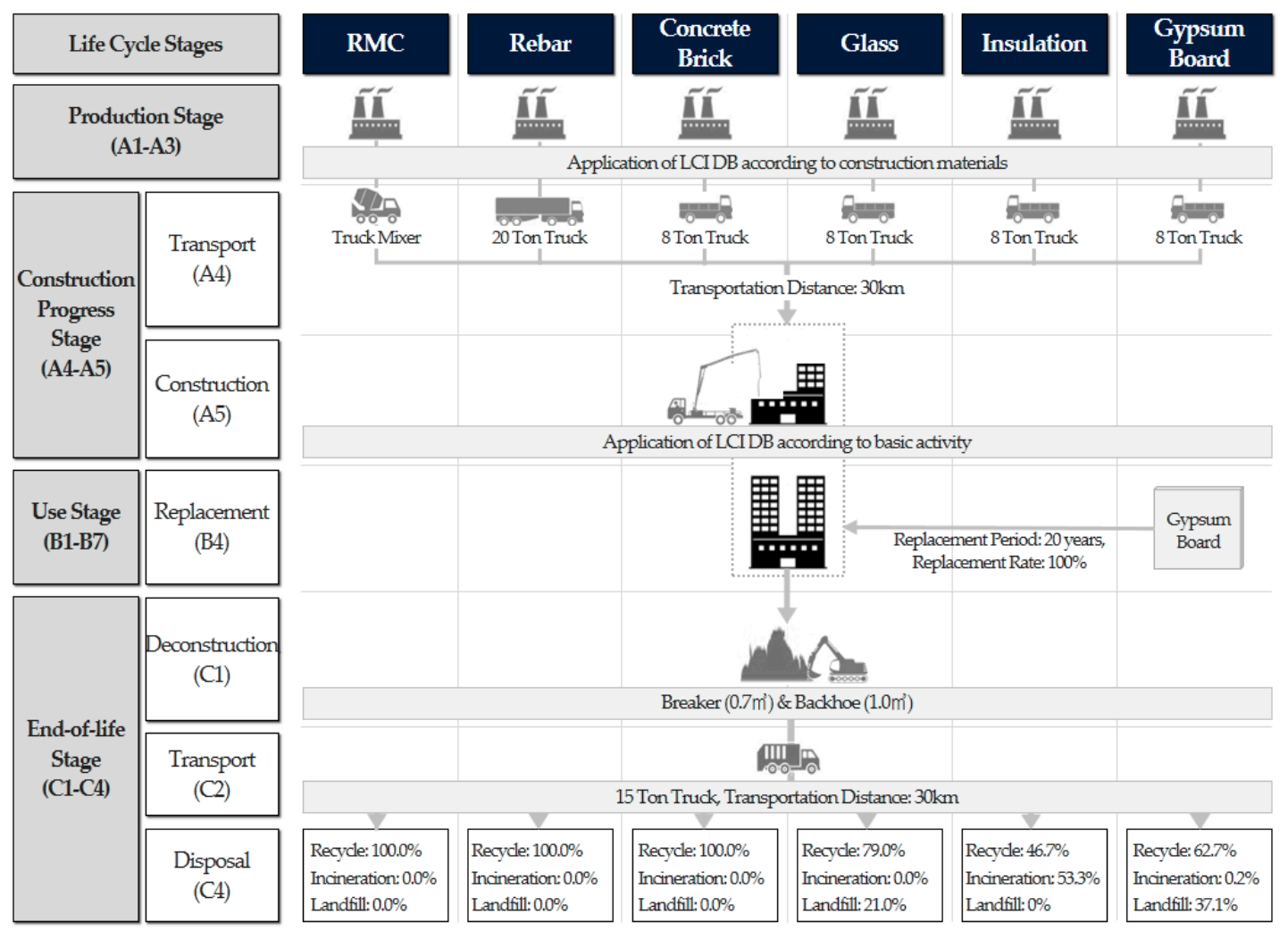

Figure 2. Life cycle scenario.

For the production stage, we applied the life cycle inventory (LCI) database of each major material. For the construction progress stage, the freight vehicle, and transport distance for each major material were based on the Standard Estimating System of Construction Work, by the Korea Institute of Civil Engineering and Building Technology [52]. For the use (maintenance/repair) stage, we set the lifespan at 40 years, drawing on the standards stipulated in the Enforcement Decree of the Corporate Income Tax Act [53], and applied the repair cycle and repair rate of each material according to the long-term repair planning standards stipulated in the Enforcement Decree of the Apartment Housing Act [54]. For the end-of-life (deconstruction/disposal) stage, demolition work involved breaker $\left(0.7 \mathrm{~m}^{3}\right)$, and backhoe $\left(1.0 \mathrm{~m}^{3}\right)$ operations [21], the quantity of waste construction materials was assumed to equal the sum of the input quantities of the six materials during the production stage. The freight vehicle and transport distance were set at 15-ton truck and $30 \mathrm{~km}$, in keeping with the Standard Estimating System of Construction Work [55], and the rates of reuse, incineration, and landfill for waste construction materials were taken from the waste construction material disposal status released by the Korea Environmental Industry and Technology Institute. 


\subsubsection{Establishing Environmental Cost Factors}

Environmental cost refers to the cost of an environmental impact, converted into a monetary value, by quantifying the related environmental issues at the end-point level and categorizing the corresponding area of protection required as a safeguard from an environmental ethical viewpoint. This can be computed using a monetary valuation-based damage cost life cycle evaluation model.

The environmental cost factor for the functional unit of each construction material was established using the life cycle scenarios for the major construction materials, LCI database, and KOLID methodology, a monetary valuation-based damage cost life cycle analysis methodology developed by the Ministry of Environment of South Korea [42]. The KOLID methodology was designed to promote the purchase of eco-friendly products by collectively evaluating not only the economic value of the purchase, use, and disposal of the product but also the value of environmental impact. This methodology quantifies 16 types of end-point damage, such as cancer, heat stress, infectious disease, skin cancer, and cataract, attributable to the six environmental impact categories (GWP, AP, EP, ODP, POCP, and ADP), and evaluates the four safeguards, consisting of human health, social assets, biodiversity, and primary production. The damage indicators of these four safeguards are the disability-adjusted life year (DALY), i.e., the number of years lost due to the following: ill-health, disability, or early death; economic burdens of suppression or depletion of agricultural crops, marine, forest, or mineral resources, and fossil fuels; the expected increase in the number of extinct species (EINES) of vascular and aquatic plants; and the net primary production (NPP), i.e., the amount $\left(\mathrm{kg} / \mathrm{m}^{2} \cdot \mathrm{yr}\right)$ of organic matter resulting from photosynthesis by terrestrial plants and marine plankton, respectively. The environmental cost is represented by the marginal willingness to pay (MWTP) for these damage indicators using the MWTP unit that established the database in the KOLID methodology. MWTP is a contingent valuation method reflecting the threshold price consumers are willing to pay in a virtual market of a given material type.

In compliance with the ISO 14040 LCI database selection criteria (namely geographical, temporal, and technological correlations), we applied the Korean LCI database (Ministry of Commerce, Industry and Energy, and Ministry of Environment) [56], the National Database on Environmental Information of Construction Materials (Korea Institute of Civil Engineering and Building Technology) [57], and the German ÖKOBAU.DAT database [58] in descending priority. We applied the German database for the landfill of construction wastes due to the lack of such information in the LCI database.

The schematic in Figure 3 represents the process of establishing the environmental cost factors of major construction materials, and Table 5 presents the resulting environmental costs.

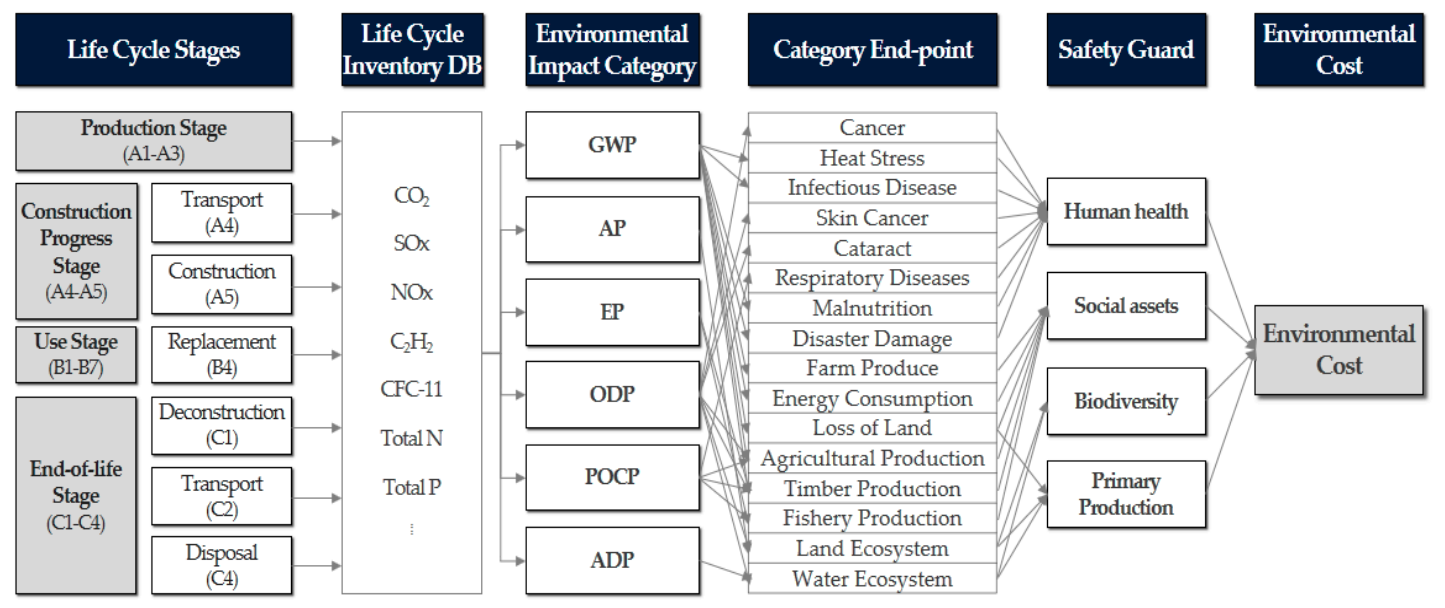

Figure 3. Process of establishing environmental cost factors. 
Table 5. Environmental cost of major construction materials.

\begin{tabular}{cccccc}
\hline RMC & Rebar & Concrete Brick & Gypsum Board & Glass & Insulation \\
\hline $18.27 \mathrm{USD} / \mathrm{m}^{3}$ & $21.78 \mathrm{USD} /$ ton & $6.79 \mathrm{USD} /$ ton & $76.94 \mathrm{USD} /$ ton & $97.19 \mathrm{USD} /$ ton & $23.71 \mathrm{USD} /$ ton \\
\hline
\end{tabular}

\subsection{Monte Carlo Simulation (MCS)}

MCS is the most widely used technique for probabilistic analysis. It consists of $\mathrm{N}$ runs using the PDFs, describing uncertain situations and randomized inputs within the PDFs derived from any random number between zero and one; the results are represented as probability distributions based on descriptive statistics $[45,46]$. The PDF for the input quantity of each major construction material was used to estimate the target population of each structure type and plan form of Korean apartment buildings, followed by analysis of the mode, median, mean, and range of the life cycle environmental costs obtained from 10,000 runs.

Sensitivity analysis was performed to identify the major construction materials (probability distribution events) that had a significant impact on the embedded environmental costs after the MCS was terminated by the event assumed to the probability distribution.

\section{Results}

Figure 4 illustrates the estimated environmental costs, presented as probability distributions. The environmental costs of each apartment building, concentrated on one single mode, show normal distributions, except the flat plate structure, which shows a left-skewed triangular distribution. This implies that the PDFs for wall structure and rigid frame structure have small deviations from their respective modes and relatively regular distributions, whereas those for the flat plate structure resulted in a skewed distribution, presumably due to its smaller sample size and larger deviation.

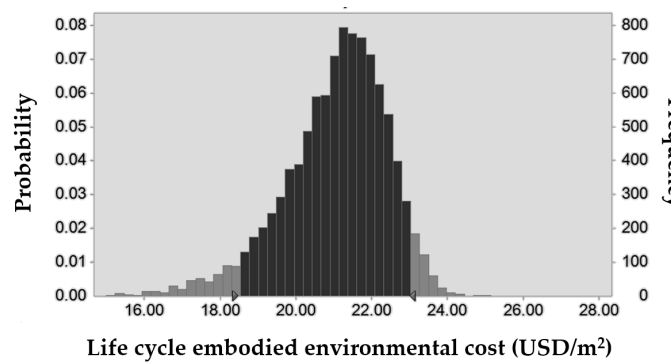

(a) Wall Structure, Plate-type

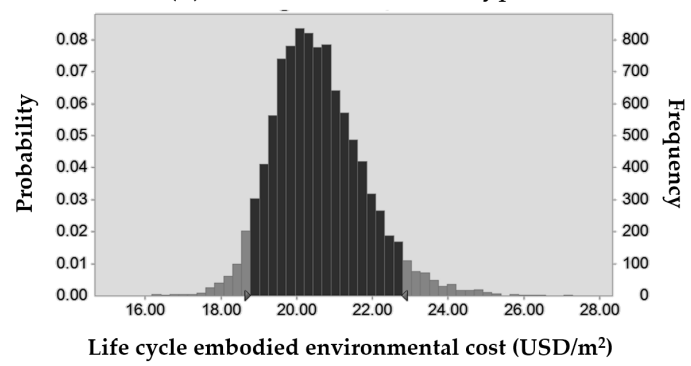

(c) Rigid Frame Structure, Plate-type

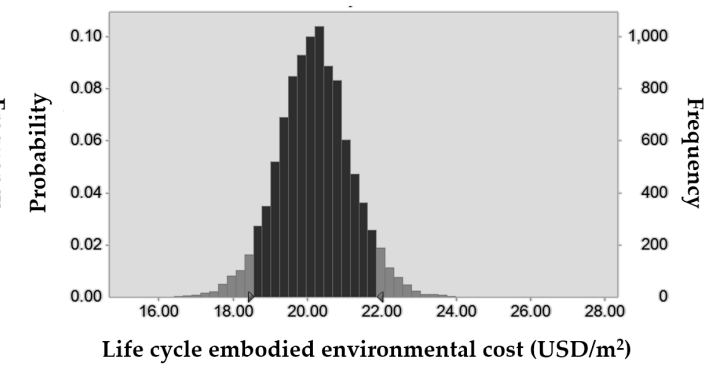

(b) Wall Structure, Tower-type

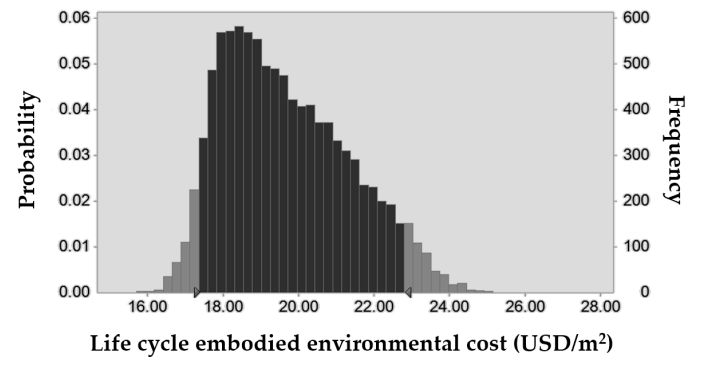

(d) Flat Plate Structure

Figure 4. Results of probabilistic life cycle environmental cost.

Table 6 presents descriptive statistics for the estimated life cycle embodied environmental costs. The environmental cost range for apartment buildings was estimated as $10.18-34.06 \mathrm{USD} / \mathrm{m}^{2}$, with the variability amounting to $\sim 72 \%$. In particular, both the minimum and maximum environmental costs related to buildings with plate-type wall structure. This finding was attributed to the larger sample group than the other structure types and plan forms, allowing a more comprehensive evaluation range. Therefore, assuming that the upper and lower $5 \%$ of the cost range, randomly estimated 
through MCS, represent unrealistic values for all input quantities of major construction materials, we re-analyzed the costs using the remaining $90 \%$. Consequently, the minimum $\left(16.87 \mathrm{USD} / \mathrm{m}^{2}\right)$ and maximum $\left(23.03 \mathrm{USD} / \mathrm{m}^{2}\right)$ costs were associated with rigid frame structure tower-type and wall structure plate-type apartment buildings, respectively. Moreover, they showed a variation ratio ranging from $14.29 \%$ to $23.84 \%$ depending on the structure type and plan form; excluding buildings with flat plate structure, which exhibited a variation ratio of $23.84 \%$ due to the small sample size, the variation ratio was found to be less than $20 \%$ in all apartment buildings.

Table 6. Result of probabilistic environmental cost of Korean apartment buildings (Unit: USD $/ \mathrm{m}^{2}$ ).

\begin{tabular}{|c|c|c|c|c|c|c|c|c|c|}
\hline \multirow{2}{*}{$\begin{array}{l}\text { Structure } \\
\text { Type }\end{array}$} & \multirow{2}{*}{ Plane Form } & \multirow{2}{*}{ Mode } & \multirow{2}{*}{ Median } & \multirow{2}{*}{ Mean } & \multirow{2}{*}{ Minimum } & \multirow{2}{*}{ Maximum } & \multicolumn{3}{|c|}{$\mathbf{9 0} \%$ Confidence Interval } \\
\hline & & & & & & & From & To & Variation Ratio \\
\hline \multirow{3}{*}{$\begin{array}{c}\text { Wall } \\
\text { Structure }\end{array}$} & Plate-type & 21.70 & 21.24 & 21.08 & 10.18 & 34.06 & 18.52 & 23.03 & $19.58 \%$ \\
\hline & Tower-type & 20.16 & 20.19 & 20.19 & 15.46 & 24.65 & 18.58 & 21.80 & $14.77 \%$ \\
\hline & Mixed-type & 20.11 & 20.25 & 20.38 & 16.89 & 26.98 & 18.96 & 22.12 & $14.29 \%$ \\
\hline Rigid & Plate-type & 20.47 & 20.49 & 20.61 & 11.50 & 33.08 & 18.84 & 22.78 & $17.30 \%$ \\
\hline Frame & Tower-type & 18.63 & 18.63 & 18.63 & 13.46 & 23.95 & 16.87 & 20.39 & $17.26 \%$ \\
\hline Structure & Mixed-type & 20.14 & 20.14 & 20.12 & 16.37 & 28.74 & 18.28 & 21.91 & $16.57 \%$ \\
\hline \multicolumn{2}{|c|}{ Flat Plate Structure } & 19.04 & 19.44 & 19.69 & 15.55 & 25.31 & 17.38 & 22.82 & $23.84 \%$ \\
\hline
\end{tabular}

In particular, the mode, median, and mean environmental costs of the apartment buildings were highest according to the sequence wall structure $>$ rigid frame structure $>$ flat plate structures, whereas at the plan form level they followed the sequence plate-type $>$ mixed-type $>$ tower type within the same structure type. The same cost level tendencies, depending on the structure type and plan form of apartment buildings, were also observed in the overlay chart (Figure 5) representing the cumulative probability of life cycle embodied environmental cost and the chart (Figure 6) representing the life cycle embodied environmental cost range at 10\%, 25\%, 50\%, and $90 \%$ confidence intervals. This was attributable primarily to the decrease in RMC input quantity, which has the highest cost intensity, depending on the structure type and plan form of the apartment building, decreasing in the sequence described above. On this note, sensitivity analysis revealed RMC to have the greatest influence on embodied environmental costs among the six materials, followed by concrete brick, rebar, insulation, glass, and gypsum board. Furthermore, in correlation analysis of the structure type and plan form, the mean correlation coefficient between RMC and life cycle embodied environmental cost was 0.82 (Figure 7), the highest among the construction materials, thus demonstrating the absolute influence of RMC on embodied environmental costs. Consequently, considering the life cycle embodied environmental cost simply in terms of the mode (which represents the highest probability of occurrence), the use of flat plate or rigid frame construction, and the tower-type wall structure, which require comparatively small input quantities of RMC, were found to be advantageous in reducing life cycle embodied environmental costs.

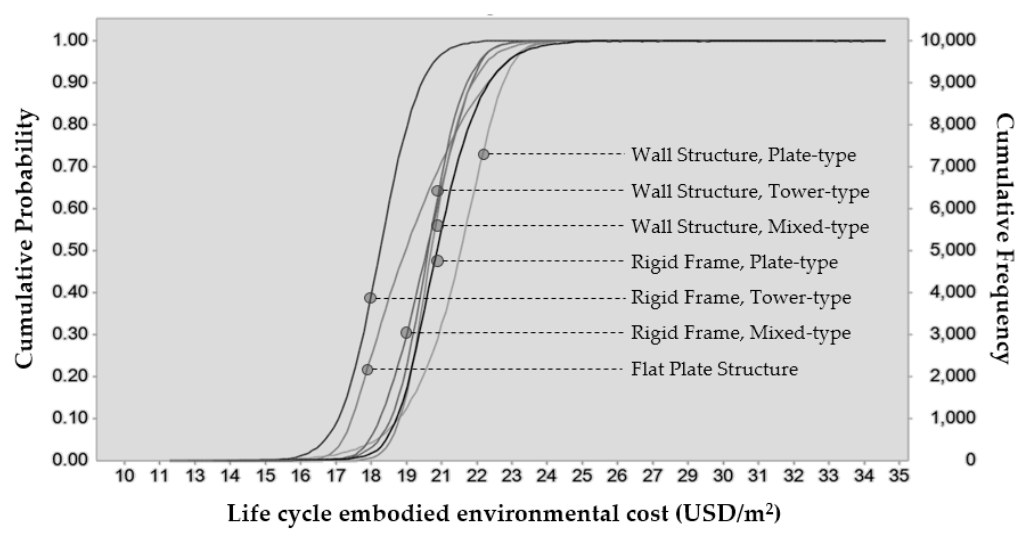

Figure 5. Cumulative probability of life cycle embodied environmental cost. 


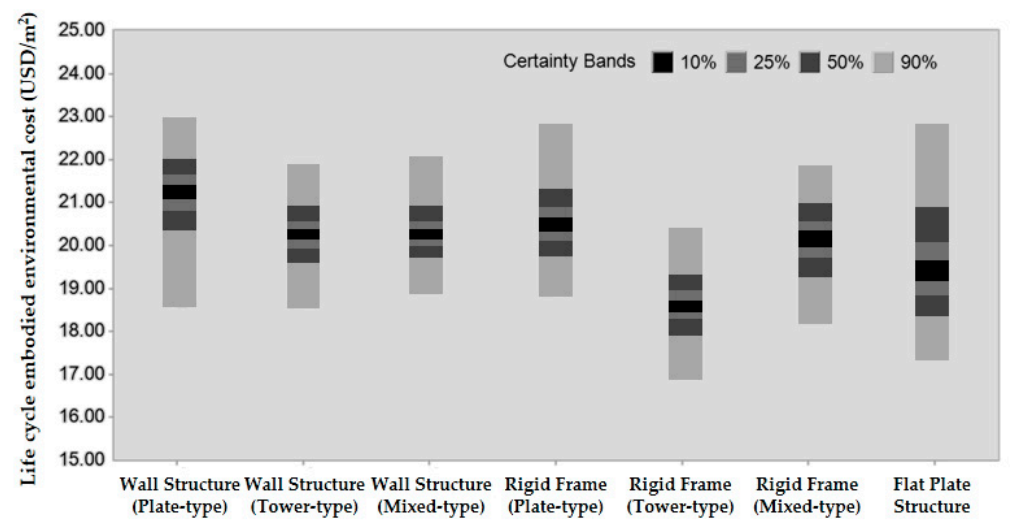

Figure 6. Range of life cycle embodied environmental cost.

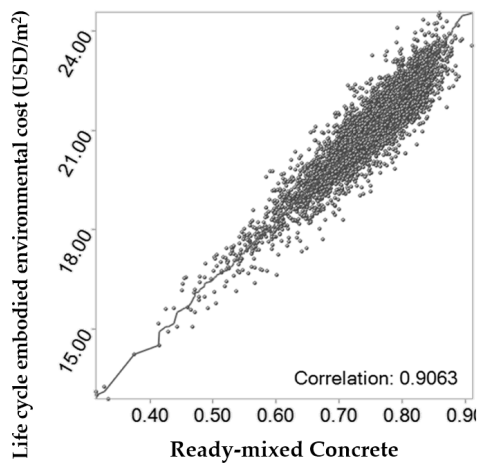

(a) Wall Structure, Plate-type

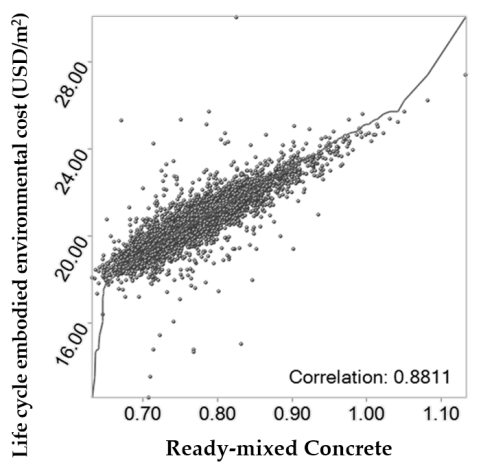

(b) Rigid Frame Structure, Plate-type

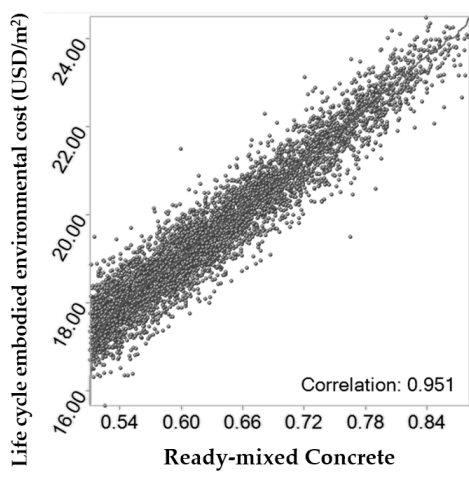

(c) Flat Plate Structure

Figure 7. Correlation analysis between life cycle embodied environmental cost and RMC.

\section{Discussion}

The majority of Korean apartment buildings were constructed using the plate-type wall structure for cost- and time-saving purposes; unfortunately, according to the present findings, the plate-type wall structure has the highest life cycle embodied environmental cost. This highlights the need for comprehensive cost analysis in the early planning stage of an apartment construction project, taking into account not only direct construction cost but also environmental cost, consequently, aiming to reduce the input quantity of RMC, which has the greatest influence on environmental cost, or using RMC that has improved environmental performance. In view of this, the findings are expected to serve as weighting factors for estimating life cycle embodied environmental cost according to structure type and plan form, for practical work within the construction sector or central/regional government, as well as basic data for selecting environmental cost reduction measures. One limitation of this study is the unequal group sizes of different structure types and plan forms, due to difficulties associated with data collection. In order to improve the data reliability and significance, a follow-up study should perform reanalysis with additional samples of flat plate structure apartment buildings.

\section{Conclusions}

This study evaluates the life cycle embodied environmental cost of Korean apartment buildings by means of probabilistic analysis, with a focus on the major construction materials, as part of analytical research into the life cycle environmental impacts of buildings. The following points summarize the major steps and findings of the study:

1. We established environmental cost factors reflecting 42 PDFs for the input quantities of six major construction materials and their life cycle scenarios, and performed MCS-based probabilistic 
analysis of the life cycle embodied environmental costs of apartment buildings according to their structure type and plan form.

2. All the resulting probability distributions concentrated on one single mode, and showed fairly normal distributions except for those concerning the flat plate construction technique.

3. The life cycle embodied environmental cost within the scope of this study ranged from 16.87 USD $/ \mathrm{m}^{2}$ to $23.03 \mathrm{USD} / \mathrm{m}^{2}$ within the $90 \%$ confidence interval, with significant variation ratios except for the flat plate structure, which showed a maximum variation ratio of $23.84 \%$.

4. Life cycle embodied environmental cost followed the sequence: wall structure $>$ rigid frame structure $>$ flat plate at the structural level; and plate-type $>$ mixed-type $>$ tower-type at the plan form level, predominantly related to a decrease in RMC input quantity.

Considering the estimated costs simply in terms of the mode, apartment buildings constructed with a flat plate or rigid frame structure, and the tower-type of wall structure were advantageous for reducing life cycle embodied environmental cost within the scope of this study.

Author Contributions: This paper was designed and written by S.R., and reviewed by R.K. and S.P.; S.T. supervised the project.

Funding: This work was supported by the research fund of Hanyang University (HY-2017).

Conflicts of Interest: The authors have no conflicts of interest to declare.

\section{References}

1. Laprise, M.; Lufkin, S.; Rey, E. An indicator system for the assessment of sustainability integrated into the project dynamics of regeneration of disused urban areas. Build. Environ. 2015, 86, 29-38. [CrossRef]

2. Zeule, L.D.O.; Vinhal, L.D.; Serra, M.S.B.; Barreto, D. Decision making process assisted by life cycle assessment: Greenhouse gas emission. Int. J. Sustain. Build. Technol. Urban Dev. 2017, 8, 244-253.

3. Kim, K.J.; Yun, W.G.; Cho, N.; Ha, J. Life cycle assessment based environmental impact estimation model for pre-stressed concrete beam bridge in the early design phase. Environ. Impact Assess. Rev. 2017, 64, 47-56. [CrossRef]

4. Roh, S.; Tae, S.; Suk, S.J.; Ford, G.; Shin, S. Development of a building life cycle carbon emissions assessment program (BEGAS 2.0) for Korea's green building index certification system. Renew. Sustain. Energy Rev. 2016, 53, 954-965. [CrossRef]

5. Ortiz, O.; Castells, F.; Sonnemann, G. Sustainability in the construction industry: A review of recent developments based on LCA. Constr. Build. Mater. 2009, 23, 28-39. [CrossRef]

6. Häkkinen, T. Systematic method for the sustainability analysis of refurbishment concepts of exterior walls. Constr. Build. Mater. 2012, 37, 783-790. [CrossRef]

7. Robichaud, L.B.; Anantatmula, V.S. Greening project management practices for sustainable construction. J. Manag. Eng. 2010, 27, 48-57. [CrossRef]

8. Zuo, J.; Zhao, Z.Y. Green building research-current status and future agenda: A review. Renew. Sustain. Energy Rev. 2014, 30, 271-281. [CrossRef]

9. Kang, H.J. Development of a systematic model for an assessment tool for sustainable buildings based on a structural framework. Energy Build. 2015, 104, 287-301. [CrossRef]

10. Lee, S.; Tae, S.; Roh, S.; Kim, T. Green template for life cycle assessment of buildings based on building information modeling: Focus on embodied environmental impact. Sustainability 2015, 7, 16498-16512. [CrossRef]

11. Ismaeel, W.S.E. Midpoint and endpoint impact categories in Green building rating systems. J. Clean. Prod. 2018, 182, 783-793. [CrossRef]

12. Arrigoni, A.; Beckett, C.; Ciancio, D.; Dotelli, G. Life cycle analysis of environmental impact vs. durability of stabilised rammed earth. Constr. Build. Mater. 2017, 142, 128-136. [CrossRef]

13. Ibn-Mohammed, T.; Greenough, R.; Taylor, S.; Ozawa-Meida, L.; Acquaye, A. Operational vs. embodied emissions in buildings-A review of current trends. Energy Build. 2013, 66, 232-245. [CrossRef]

14. Duggan, A.R.; McCabe, B.A.; Goggins, J.; Clifford, E. An embodied carbon and embodied energy appraisal of a section of Irish motorway constructed in peatlands. Constr. Build. Mater. 2015, 79, 402-419. [CrossRef] 
15. Roh, S.; Tae, S. An integrated assessment system for managing life cycle $\mathrm{CO}_{2}$ emissions of a building. Renew. Sustain. Energy Rev. 2017, 73, 265-275. [CrossRef]

16. Geng, S.; Wang, Y.; Zuo, J.; Zhou, Z.; Du, H.; Mao, G. Building life cycle assessment research: A review by bibliometric analysis. Renew. Sustain. Energy Rev. 2017, 76, 176-184. [CrossRef]

17. Häfliger, I.F.; John, V.; Passer, A.; Lasvaux, S.; Hoxha, E.; Saade, M.R.M.; Habert, G. Buildings environmental impacts' sensitivity related to LCA modelling choices of construction materials. J. Clean. Prod. 2017, 156, 805-816. [CrossRef]

18. Jeong, K.; Ji, C.; Koo, C.; Hong, T.; Park, H.S. A model for predicting the environmental impacts of educational facilities in the project planning phase. J. Clean. Prod. 2015, 107, 538-549. [CrossRef]

19. Wang, T.; Seo, S.; Liao, P.C.; Fang, D. GHG emission reduction performance of state-of-the-art green buildings: Review of two case studies. Renew. Sustain. Energy Rev. 2016, 56, 484-493. [CrossRef]

20. Kumanayake, R.; Luo, H.; Paulusz, N. Assessment of material related embodied carbon of an office building in Sri Lanka. Energy Build. 2018, 166, 250-257. [CrossRef]

21. Roh, S.; Tae, S.; Shin, S.; Woo, J. Development of an optimum design program (SUSB-OPTIMUM) for the life cycle $\mathrm{CO}_{2}$ assessment of an apartment house in Korea. Build. Environ. 2014, 73, 40-54. [CrossRef]

22. Salcido, J.C.; Raheem, A.A.; Ravi, S. Comparison of embodied energy and environmental impact of alternative materials used in reticulated dome construction. Build. Environ. 2016, 96, 22-34. [CrossRef]

23. Bin Marsono, A.K.; Balasbaneh, A.T. Combinations of building construction material for residential building for the global warming mitigation for Malaysia. Constr. Build. Mater. 2015, 85, 100-108. [CrossRef]

24. Vieira, D.R.; Calmon, J.L.; Coelho, F.Z. Life cycle assessment (LCA) applied to the manufacturing of common and ecological concrete: A review. Constr. Build. Mater. 2016, 124, 656-666. [CrossRef]

25. Lee, N.; Tae, S.; Gong, Y.; Roh, S. Integrated building life-cycle assessment model to support South Korea's green building certification system (G-SEED). Renew. Sustain. Energy Rev. 2017, 76, 43-50. [CrossRef]

26. de Klijn-Chevalerias, M.; Javed, S. The Dutch approach for assessing and reducing environmental impacts of building materials. Build. Environ. 2017, 111, 147-159. [CrossRef]

27. Roh, S.; Tae, S.; Shin, S. Development of building materials embodied greenhouse gases assessment criteria and system (BEGAS) in the newly revised Korea Green Building Certification System (G-SEED). Renew. Sustain. Energy Rev. 2014, 35, 410-421. [CrossRef]

28. Ospina, A.P.; Castaño, A.G.; Restrepo, L.M. LEED certification and the new standard of sustainable construction in Colombia. Int. J. Sustain. Build. Technol. Urban Dev. 2017, 8, 125-134.

29. Illankoon, I.M.C.S.; Tam, V.W.Y.; Le, K.N.; Shen, L. Key credit criteria among international green building rating tools. J. Clean. Prod. 2017, 164, 209-220. [CrossRef]

30. Zhang, L.; Wu, J.; Liu, H. Turning green into gold: A review on the economics of green buildings. J. Clean. Prod. 2018, 172, 2234-2245. [CrossRef]

31. Huang, B.; Chen, Y.; McDowall, W.; Türkeli, S.; Bleischwitz, R. Embodied GHG emissions of building materials in Shanghai. J. Clean. Prod. 2019, 210, 777-785. [CrossRef]

32. Basbagill, J.; Flager, F.; Lepech, M.; Fischer, M. Application of life-cycle assessment to early stage building design for reduced embodied environmental impacts. Build. Environ. 2013, 60, 81-92. [CrossRef]

33. Azari, R.; Abbasabadi, N. Embodied energy of buildings: A review of data, methods, challenges, and research trends. Energy Build. 2018, 168, 225-235. [CrossRef]

34. Meneghelli, A. Whole-building embodied carbon of a North American LEED-certified library: Sensitivity analysis of the environmental impact of buildings materials. Build. Environ. 2018, 134, 230-241. [CrossRef]

35. Malmqvist, T.; Nehasilova, M.; Moncaster, A.; Birgisdottir, H.; Rasmussen, F.N.; Wiberg, A.H.; Potting, J. Design and construction strategies for reducing embodied impacts from buildings-Case study analysis. Energy Build. 2018, 166, 35-47. [CrossRef]

36. Chastas, P.; Theodosiou, T.; Kontoleon, K.J.; Bikas, D. Normalising and assessing carbon emissions in the building sector: A review on the embodied $\mathrm{CO}_{2}$ emissions of residential buildings. Build. Environ. 2018, 130, 212-226. [CrossRef]

37. Li, X.; Yang, F.; Zhu, Y.; Gao, Y. An assessment framework for analyzing the embodied carbon impacts of residential buildings in China. Energy Build. 2014, 85, 400-409. [CrossRef]

38. Chen, Y.; $\mathrm{Ng}$, S.T. Factoring in embodied GHG emissions when assessing the environmental performance of building. Sustain. Cities Soc. 2016, 27, 244-252. [CrossRef] 
39. Evangelista, P.P.A.; Kiperstok, A.; Torres, E.A.; Gonçalves, J.P. Environmental performance analysis of residential buildings in Brazil using life cycle assessment (LCA). Constr. Build. Mater. 2018, 169, 748-761. [CrossRef]

40. Kua, H.W.; Lu, Y. Environmental impacts of substituting tempered glass with polycarbonate in construction-An attributional and consequential life cycle perspective. J. Clean. Prod. 2016, 137, 910-921. [CrossRef]

41. Roh, S.; Tae, S.; Kim, R. Analysis of Embodied Environmental Impacts of Korean Apartment Buildings Considering Major Building Materials. Sustainability 2018, 10, 1693. [CrossRef]

42. Korea Environmental Industry \& Technology Institute. Development of Integrated Evaluation Technology on Product Value for Dissemination of Environmentally Preferable Products; Korea Ministry of Environment: Sejong, Korea, 2009.

43. Roh, S.; Tae, S.; Suk, S.J.; Ford, G. Evaluating the embodied environmental impacts of major building tasks and materials of apartment buildings in Korea. Renew. Sustain. Energy Rev. 2017, 73, 135-144. [CrossRef]

44. Zhang, X.; Wang, F. Stochastic analysis of embodied emissions of building construction: A comparative case study in China. Energy Build. 2017, 151, 574-584. [CrossRef]

45. Bersimis, S.; Georgakellos, D. A probabilistic framework for the evaluation of products' environmental performance using life cycle approach and Principal Component Analysis. J. Clean. Prod. 2013, 42, 103-115. [CrossRef]

46. Bieda, B. Application of stochastic approach based on Monte Carlo (MC) simulation for life cycle inventory (LCI) to the steel process chain: Case study. Sci. Total Environ. 2014, 481, 649-655. [CrossRef] [PubMed]

47. ISO 14044. Environmental Management_Life Cycle Assessment_Requirements and Guidelines; ISO: Geneva, Switzerland, 2006.

48. Shin, S.; Tae, S.; Woo, J.; Roh, S. The development of environmental load evaluation system of a standard Korean apartment house. Renew. Sustain. Energy Rev. 2011, 15, 1239-1249. [CrossRef]

49. Pacheco-Torgal, F.; Faria, J.; Jalali, S. Embodied energy versus operational energy showing the shortcomings of the energy performance building directive (EPBD). Mater. Sci. Forum 2013, 730-732, 587-591. [CrossRef]

50. Biswas, W.K. Carbon footprint and embodied energy consumption assessment of building construction works in Western Australia. Int. J. Sustain. Built Environ. 2014, 3, 179-186. [CrossRef]

51. EN 15804. Sustainability of Construction Works—Environmental Product Declarations-Core Rules for the Product Category of Construction Products; CEN: Brussels, Belgium, 2012.

52. Korea Institute of Civil Engineering and Building Technology (KICT). Standard Estimating System of the Construction Work; KICT: Goyang, Korea, 2017.

53. Korea Corporate Tax Act: Korea Ministry of Strategy and Finance. Available online: http:/ / elaw.klri.re.kr/ kor_service/lawView.do?hseq=28577\&lang=ENG (accessed on 26 October 2018).

54. Korea Ministry of Land, Infrastructure and Transport. Korea Housing Act. Available online: http:/ / elaw. klri.re.kr/kor_service/lawView.do?hseq=25579\&lang=ENG (accessed on 26 October 2018).

55. Korea Environmental Industry \& Technology Institute (KEITI). Waste Statistics; KEITI: Seoul, Korea, 2017.

56. Korea Environmental Industry \& Technology Institute (KEITI). Korea Life Cycle Inventory Database. 2004. Available online: http:/ / www.edp.or.kr/lci/lci_db.asp (accessed on 26 October 2018).

57. Korea Institute of Civil Engineering and Building Technology. The Final Report of National DB on Environmental Information of Building Materials; KICT: Goyang, Korea, 2008.

58. Germany Federal Ministry of the Interior, Building and Community. Oekobaudat. 2017. Available online: http:/ / www.oekobaudat.de/en/database/database-oekobaudat.html (accessed on 26 October 2018).

(C) 2019 by the authors. Licensee MDPI, Basel, Switzerland. This article is an open access article distributed under the terms and conditions of the Creative Commons Attribution (CC BY) license (http://creativecommons.org/licenses/by/4.0/). 